\title{
Penerapan Model Pembelajaran Sains Teknologi Masyarakat dan Pengaruhnya Terhadap Hasil Belajar ditinjau dari Kemampuan Matematis
}

\author{
Hafidz $^{1)}$, Nanik Suhernawati ${ }^{2)}$, Rafif Addarquthni ${ }^{3)}$ \\ ${ }^{1)}$ MTs. Syirkah Salafiyah, ${ }^{2}$ SMPN 2 Ambulu, ${ }^{3)}$ SMPN 2 Rambipuji \\ Email:boyhafidz49@gmail.com,linawahyu79@gmail.com,rafif.addarquthni@gmail.com
}

\begin{abstract}
So far there is still a growing view that social and scientific scientific development are two separate entities. Science and social work in different directions even across from shared values. Interest in developing science sometimes does not consider the needs and desires of the community as a representation of the social realm, and vice versa. Learning with the Community Technology Science model will provide solution answers to scientific and social ego issues so that they will hack into the relationship between the two. The Community Technology Science learning model will present learning that instills an understanding that between science and social must go together, the development of science must answer the needs and interests of society. This study tries to apply the Science Technology Community learning model with a review of the mathematical ability of its influence on learning outcomes. This study uses a hypothesis test ( $\mathrm{T}$ test) using a statistical program and is a type of quantitative causality research. The research locations were Ambulu SMPN 2 and Rambipuji 2 Public Middle School with respondents as students of the two schools.

Keywords: Community Technology Science, Learning Outcomes, Mathematical Ability
\end{abstract}

\begin{abstract}
ABSTRAK
Selama ini masih berkembang pandangan bahwa pengembangan keilmuan sosial dan sains adalah dua entitas yang terpisah. Sains dan sosial berjalan dengan arah yang berbeda bahkan berseberangan jauh dari nilai kebersamaan. Kepentingan dalam pengembangan sains terkadang tidak mempertimbangkan kebutuhan dan keinginan masyarakat sebagai representasi dari ranah sosial, demikian pula sebaliknya. Pembelajaran dengan model Sains Teknologi Masyarakat akan memberikan jawaban solusif terhadap permasalahan ego keilmuan sains dan sosial sehingga akan meretas keterhubungan keduanya. Model pembelajaran Sains Teknologi Masyarakat akan menyajikan pembelajaran yang menanamkan pemahaman bahwa antara sains dan sosial harus berjalan bersama, pengembangan sains harus menjawab terhadap kebutuhan dan kepentingan masyarakat. Penelitian ini mencoba menerapkan model pembelajaran Sains Teknologi Masyarakat dengan tinjauan kemampuan matematis
\end{abstract}


pengaruhnya terhadap hasil belajar. Penelitian ini menggunakan uji hipotesis (uji T) menggunakan program statistik dan merupakan jenis penelitian kuantitatif kausalitas. Lokasi penelitian adalah SMPN 2 Ambulu dan SMPN 2 Rambipuji dengan responden adalah siswa kedua sekolah tersebut.

Kata Kunci : Sains Teknologi Masyarakat, Hasil Belajar, Kemampuan Matematis

\section{PENDAHULUAN}

Perkembangan teknologi dewasa ini sangat pesat dan tanpa batas dalam hal penggunaannya baik sekat pemisah usia maupun pranata sosial. Pemanfaatan teknologi (sains) dalam kehidupan masyarakat sangatlah masif dan tidak dapat dipisahkan lagi. Sains teknologi telah menjadi bagian kehidupan pada seluruh aspek, namun negatifnya masyarakat lebih banyak sebagai pengguna pasif dan cenderung menerima apapun produk sains teknologi tanpa terakomodir kebutuhan dan kepentinggnya. Kebutuhan dan kepentingan masyarakat adalah terciptanya kehidupan yang baik dan berkelanjutan bukan hanya kenikmatan sesaat sebagaimana beberapa dampak pengembangan sains yang justru berdampak buruk bagi kehidupan.

Urgensi teknologi sains berlandaskan kepentingan masyarakat perlu ditanamkan pada pembelajaran sehingga akan membentuk generasi masa depan yang mempuni dan menyadari kepentingan tersebut. Pembelajaran dengan corak sebagaimana dimaksudkan adalah model pembelajaran Sains Teknologi Masyarakat (STM) yang sangat relevan bila diimplementasikan dalam kegiatan belajar mengajar. Pembelajaran STM adalah pembelajaran yang tidak hanya menguasai konsep saja, akan tetapi mengaitkan konsep-konsep sains dengan kepentingan masyarakat (Hidayat, 2009). Dengan adanya pertimbangan kepentingan masyarakat maka pengembangan sains dan teknologi akan semakin baik dan jauh dari timbulnya dampak buruk. Analisa yang nyata terkait dampak buruk pengembangan sains teknologi tanpa mempertimbangkan kepentingan masyarakat adalah dalam kasus Lapindo Brantas Sidoarjo dan kasus lainnya.

Fenomena ini tidak dapat dibiarkan berlarut, perlu adanya kesadaran bersama melalui pembelajaran pada tataran sekolah. Selain penerapan model pembelajaran Sains Teknologi Masyarakat hal lain yang bertautan adalah kemampuan matematis. Kemampuan matematis adalah kemampuan internal siswa yang mendukung terhadap keberhasilan dalam perhitungan secara tepat termasuk juga pada perhitungan dampak 
yang ditimbulkan dari pengembangan sains teknologi. Berdasarkan hal tersebut, maka penelitian ini mencoba menerapkan model pembelajaran dan tinjauan faktor internal siswa sebagaimana disebutkan sehingga judul penelitian ini adalah” Penerapan Model Pembelajaran Sains Teknologi Masyarakat dan Pengaruhnya terhadap Hasil Belajar Ditinjau dari Kemampuan Matematis". Adapun tempat penelitian ini adalah SMPN 2 Ambulu dan SMPN 2 Rambipuji Semester Ganjil Tahun Pelajaran 2018/2019 dengan responden kelas VII sejumlah 120 siswa.

\section{METODE PENELITIAN}

Analisis yang akan dilakukan dalam penelitian ini adalah pengaruh penerapan model pembelajaran Sains Teknologi Masyarakat terhadap hasil belajar dengan tinjauan kemampuan matematis. Karena akan melihat pengaruh suatu variabel tertentu atau variabel bebas terhadap variabel lain yang kemudian disebut variabel terikat, maka penelitian ini adalah jenis kausal masuk pada rumpun kuantitatif (Suharsimi, 2002). Pada penelitian ini akan dilakukan uji hipotesis dengan terlebih dahulu melakukan ujia normalitas dan homogenitas data melalui perhitungan statistik program SPSS. Tinjauan kemampuan matematis dilakukan dengan tes kemampuan matematis yang telah divalidasi dan diuji taraf kesukarannya. Instrumen yang digunakan adalah 1) rubrik wawancara, 2) lembar observasi, 3) soal, 4) tes kemampuan matematis dan 5) dokumentasi.

\section{HASIL DAN PEMBAHASAN}

Model pembelajaran mempunyai kekhasan atau ciri utama adalah pada tahapan pembelajaran yang lengkap, sistematis dan runtun. Sains Teknologi Masyarakat merupakan model pembelajaran karena mempunyai tahapan pembelajaran atau sintaks yang jelas. Tahapan dari model pembelajaran Sains Teknologi Masyarakat yaitu : pendahuluan, proses pembentukan konsep, aplikasi konsep dalam kehidupan, penilaian atau evaluasi (Hidayat, 2009). Tahapan tersebut dipaparkan adalam sintaks Model Pembelajaran Sains Teknologi Masyarakat berikut ini: 
Tabel 1. Sintaks Model Pembelajaran STM

\begin{tabular}{|c|c|c|}
\hline TAHAPAN & GURU & SISWA \\
\hline Pendahuluan & \begin{tabular}{lrr} 
Guru & \multicolumn{2}{c}{ mengemukakan } \\
masalah yang & ada \\
dimasyarakat yang dapat \\
digali dari siswa atau \\
mengaitkan peristiwa yang \\
diketahui siswa dengan \\
materi.
\end{tabular} & $\begin{array}{l}\text { Siswa berinteraksi dengan guru } \\
\text { mengemukakan isu-isu atau } \\
\text { masalah yang ada dimasyarakat } \\
\text { atau peristiwa yang telah mereka } \\
\text { ketahui }\end{array}$ \\
\hline $\begin{array}{l}\text { Proses } \\
\text { pembentukan } \\
\text { konsep }\end{array}$ & $\begin{array}{l}\text { Guru menggunakan berbagai } \\
\text { metode (yang dalam } \\
\text { penelitian ini adalah proyek } \\
\text { dan eksperimen) dalam } \\
\text { menganalisis/menyelesaikan } \\
\text { masalah yang telah } \\
\text { disampaikan. }\end{array}$ & $\begin{array}{l}\text { Siswa } \\
\text { menganalisis/menyelesaikan } \\
\text { masalah yang telah mereka } \\
\text { temukan dengan metode yang } \\
\text { diberikan dari guru. }\end{array}$ \\
\hline Aplikasi kons & $\begin{array}{l}\text { Guru mengajak } r \text { siswa } \\
\text { berfikir bahwa konsep- } \\
\text { konsep yang telah dipahami } \\
\text { siswa dapat diaplikasikan } \\
\text { dalam kehidupan mereka } \\
\text { sehari-hari }\end{array}$ & $\begin{array}{l}\text { Dengan konsep yang telah } \\
\text { dipahami, siswa mengaplikasikan } \\
\text { konsep tersebut dalam kehidupan } \\
\text { mereka sehari-hari }\end{array}$ \\
\hline $\begin{array}{l}\text { Pemantapan } \\
\text { konsep dalam } \\
\text { kehidupan }\end{array}$ & $\begin{array}{l}\text { Guru meluruskan kalau ada } \\
\text { miskonsepsi selama kegiatan } \\
\text { berlangsung dan ditekankan } \\
\text { diakhir pembelajaran }\end{array}$ & $\begin{array}{l}\text { Siswa menyebutkan kembali } \\
\text { konsep yang didapatkan dari } \\
\text { pembelajaran }\end{array}$ \\
\hline $\begin{array}{l}\text { Penilaian atau } \\
\text { evaluasi. }\end{array}$ & $\begin{array}{l}\text { Guru mengevaluasi kegiatan } \\
\text { pembelajaran STM yang } \\
\text { telah dilaksanakan }\end{array}$ & $\begin{array}{l}\text { Siswa melaksanakan evaluasi } \\
\text { yang diberikan guru }\end{array}$ \\
\hline
\end{tabular}

Tahap pertama yaitu pendahuluan. Tahap ini merupakan tahap kekhasan dari pendekatan STM, pada tahap ini dikemukakan isu-isu atau masalah yang ada di masyarakat. Apersepsi dalam kehidupan dilakukan, yaitu mengaitkan peristiwa yang telah diketahui siswa dengan materi yang akan dibahas, sehingga nampak adanya kesinambuangan pengetahuan, karena diawali dengan hal-hal yang telah diketahui siswa sebelumnya yang ditekankan pada keadaan yang ditemui dalam keadaan seharihari. Pada tahap pendahuluan ini dilakukan eksplorasi pada siswa melalui pemberian tugas untuk studi lapangan dan mengobservasi keadaan. Manfaat dikemukakannya 
masalah pada awal pembelajaran membantu siswa dalam berfikir untuk menganalisa isu tersebut, dengan demikian akan ada interaksi antara guru dengan siswa dan siswa dengan siswa yang lain.

Tahap kedua adalah tahap proses pembentukan konsep. Pada tahap ini siswa diarahkan agar dapat memahami apakah analisis terhadap isu-isu atau penyelesaian terhadap masalah yang dikemukakan diawal pembelajaran telah menggunakan konsep-konsep yang diikuti ilmuwan. Siswa dapat mengalami konfilk kognitif apabila pandangan yang telah direncanakan tidak sesuai dengan yang lain. Namun, setelah berdiskusi, mendengar penjelasan orang lain dengan alasan yang dapat diterima, ia menyadari dan mengambil keputusan bahwa pandangannya perlu dirubah dalam menghadapi persoalan teretentu, Inilah kegunaan dari metode yang menggunakan interaksi sosial. Pada tahap ini akan muncul konstruksi dan rekonstruksi kognitif siswa menemukan konsep-konsep yang benar atau merupakan konsep-konsep para ilmuwan.

Tahap selanjutnya adalah aplikasi konsep dalam kehidupan. Selama proses pembentukan konsep, penyelesaian masalah dan atau analisis isu, guru perlu meluruskan kalau ada miskonsepsi selama kegiatan berlangsung, apabila sudah tidak ada miskonsepsi, guru tetap perlu melakukan pemantapan konsep melalui pemantapan konsep-konsep kunci yang penting diketahui dalam kajian tertentu, karena sangat mungkin terjadi bahwa siswa masih mengalami miskonsepsi tetapi tidak terdeteksi oleh guru. Pemantapan konsep dilakukan diakhir pembelajaran, karena konsep-konsep kunci yang ditekankan pada akhir pembelajaran akan memiliki retensi lebih lama.

Tahap terakhir adalah tahap evaluasi/penilaian. Sebagaimana pada umumnya, tujuan evaluasi atau penilaian adalah untuk mengetahui capaian pembelajaran dari suatu proses pembelajaran menggunakan model Sains Teknologi Masyarakat. Penilaian terhadap hasil belajar yang dalam penelitian ini sebagai variabel terikat adalah pada aspek kognitif dan afektif. Penilaian aspek kognitif adalah berdasarkan asumsi bahwa pembelajaran lebih menekankan adanya penyajian materi sains teknologi dan sosial kemasyarakatan yang menuntut pemahaman dan analisis. Sedangkan penilaian aspek afektif didasarkan pada pertimbangan sikap siswa setelah mengikuti proses pembelajaran.

Berdasarkan tahapan tersebut, maka nampak bahwa model pembelajaran Sains Teknologi Masyarakat menuntut adanya keaktifan siswa dan kemampuan 
perhitungan yang mumpuni sebagai syarat pembelajaran rumpun sains. Kemampuan matematis sebenarnya dapat dipandang sebagai kemampuan dasar yang harus dimiliki mengingat hampir seluruh bidang tidak terlepas dari unsur matematika. Kemampuan matematis (mathematical ability) dapat didefinisikan berdasarkan klasifikasi atau jenis dari kemampuan ini yaitu: (1) Understanding Number, (2) Non-Numerical Processes, (3) Computation and Knowledge (Kovas, 2007). Understanding Number adalah kemampuan tentang angka dan proses aljabar untuk digunakan ketika menyelesaikan permasalahan hitungan. Non-Numerical Processes adalah kemampuan dalam memahami proses matematika yang bukan angka dan memahami konsep-konsep seperti perputaran atau pencerminan simetris dan operasi spasial lainnya. Pertanyaan yang ada tidak mengandung angka yang signifikan yang perlu diperhatikan anak. Sedangkan Computation and Knowledge adalah kemampuan untuk melakukan perhitungan sederhana menggunakan, metode kertas-pensil dan mengingat kembali fakta matematika dan istilah-istilahnya. Berdasarkan hal ini, maka untuk mengukur kemampuan matematis digunakan tes dengan kisi-kisi sebagai berikut;

Tabel 2. Kisi dan Soal Tes Kemampuan Matematis

\begin{tabular}{|c|c|}
\hline INDIKATOR & PERTANYAAN DAN JAWABAN \\
\hline \multirow{9}{*}{$\begin{array}{l}\text { Penjumlahan dua } \\
\text { bilangan real/ } \\
\text { lebih dengan cepat }\end{array}$} & $\mathrm{A}=47889+2156+4258$, maka nilai $\mathrm{A}=\ldots \quad(\mathrm{A})$ \\
\hline & Jika $\mathrm{c}=2323+3223+1223$. maka nilai c adalah $\ldots$ (C) \\
\hline & A.6566 B. 6666 C. 6768 D. 6769 E. 6966 \\
\hline & $\begin{array}{l}\text { Jika } B=0,6699+0,4433+0,0111 \text {, maka nilai B adalah... } \\
\text { (B) }\end{array}$ \\
\hline & A. 1,1234 B. 1,1243 C. 1,1324 D. $1,1423 \quad$ E. 1,4321 \\
\hline & Hasil penjumlahan dari $\frac{1}{2}+\frac{2}{3}+\frac{3}{4}+1 \frac{1}{3}$ sama dengan...(E) \\
\hline & A. $1 \frac{1}{12} \quad$ B $2 \frac{1}{4} \quad$ C $3 \frac{1}{12} \quad$ D $3 \frac{5}{12}$ E $3 \frac{1}{4}$ \\
\hline & $3 \frac{1}{2}+4 \frac{1}{3}+5 \frac{1}{5}$ sama nilainya dengan... (A) \\
\hline & A. $13 \frac{1}{30} \quad$ B $\quad 13 \frac{11}{30} \quad$ C $14 \frac{1}{30} \quad$ D $14 \frac{11}{30} \quad$ E $15 \frac{1}{30}$ \\
\hline \multirow{3}{*}{$\begin{array}{l}\text { Pengurangan dua } \\
\text { bilangan real/ } \\
\text { lebih dengan cepat }\end{array}$} & $Y=70304-43625$, maka nilai $Y$ sama dengan... (E) \\
\hline & $\begin{array}{lllll}\text { A. } 36767 & \text { B. } 36677 & \text { C. } 35679 & \text { D. } 27769 & \text { E. } 26679\end{array}$ \\
\hline & 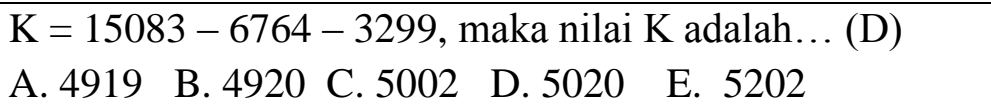 \\
\hline
\end{tabular}




\begin{tabular}{|c|c|}
\hline & 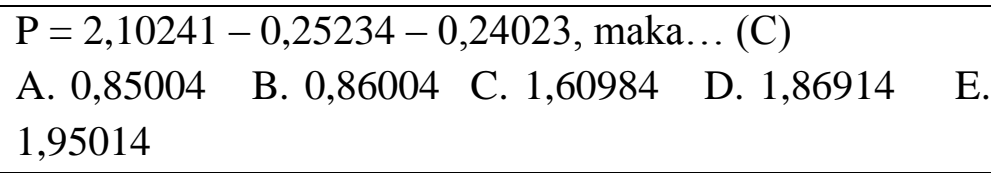 \\
\hline & $\begin{array}{l}\text { Nilai dari } 7 \frac{5}{6}-3 \frac{2}{3}-\frac{3}{4} \text { adalah... (A) } \\
\begin{array}{l}\text { A. } 3 \frac{5}{12} \quad \text { B } 3 \frac{5}{6} \text { C } 4 \frac{5}{12} \text { D } 4 \frac{5}{6} \text { E } 5 \frac{1}{6}\end{array}\end{array}$ \\
\hline & 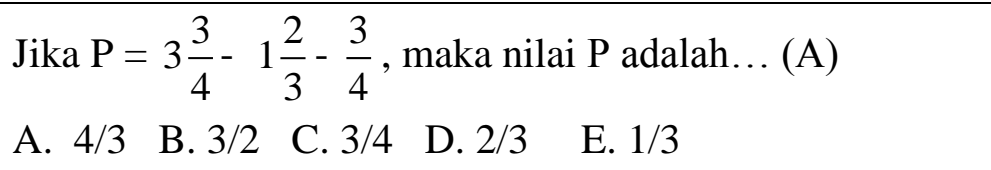 \\
\hline \multirow{5}{*}{$\begin{array}{l}\text { Perkalian dua } \\
\text { bilangan real/ } \\
\text { lebih dengan cepat }\end{array}$} & $\begin{array}{l}\text { Hasil perkalian dari } 1325 \text { dengan } 46 \text { adalah... (B) } \\
\begin{array}{lllll}\text { A. } 60140 & \text { B. } 60950 & \text { C. } 70140 & \text { D. } 70951 & \text { E. } 71140\end{array}\end{array}$ \\
\hline & $\mathrm{Z}=6,5 \times 2,75$, maka nilai $\mathrm{Z}$ adalah... (D) \\
\hline & 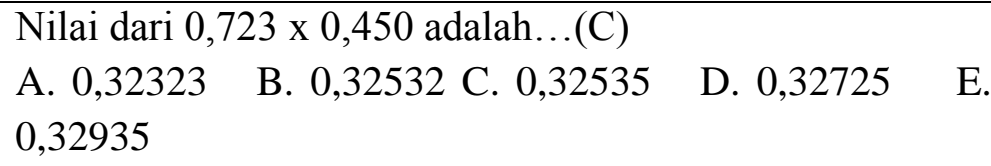 \\
\hline & $\begin{array}{lllll}\text { A. } \frac{1}{5} & \text { B. } \frac{5}{9} & \text { C. } \frac{9}{5} & \text { D. } 5 & \text { E. } \frac{18}{80}\end{array}$ \\
\hline & 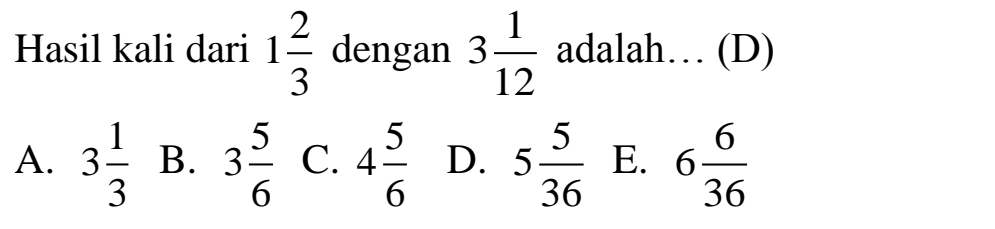 \\
\hline \multirow{6}{*}{$\begin{array}{l}\text { Pembagian dua } \\
\text { bilangan real/ } \\
\text { lebih dengan cepat }\end{array}$} & Hasil bagi dari 1111000 dengan 125 adalah... (D) \\
\hline & $\mathrm{X}=19,5: 0,65$, maka nilai $\mathrm{X}$ adalah... (B) \\
\hline & Hasil bagi dari 3,012 dengan 0,03 adalah... (B) \\
\hline & Hasil bagi dari $\frac{1}{2}$ dengan 5 adalah... (B) \\
\hline & $\begin{array}{lllll}\text { A. } \frac{1}{20} & \text { B. } \frac{1}{10} & \text { C. } \frac{2}{3} & \text { D. } \frac{5}{2} & \text { E. } 10\end{array}$ \\
\hline & Hasil bagi dari $\frac{3}{7}$ oleh $\frac{5}{6}$ adalah... (B) \\
\hline
\end{tabular}




\begin{tabular}{|c|c|}
\hline & $\begin{array}{lllll}\text { A } \frac{35}{18} & \text { B. } \frac{18}{35} & \text { C. } \frac{2}{14} & \text { D. } \frac{1}{14} & \text { E. } \frac{2}{21}\end{array}$ \\
\hline \multirow[t]{5}{*}{ Kesebandingan } & $3 \mathrm{c}=5$, maka $7 \mathrm{c}=\ldots$ (D) \\
\hline & $\begin{array}{l}0,250 \mathrm{k}=0,167 \text {, maka } 0,333 \mathrm{k}=\ldots(\mathrm{B}) \\
\begin{array}{llll}\text { A. } 0,21 & \text { B. } 0,22 \text { C. } 0,23 & \text { D. } 0,24 & \text { E. } 0,25\end{array}\end{array}$ \\
\hline & $\begin{array}{l}\text { Jika } 5 \text { butir kelapa dapat ditukar dengan } \frac{7}{5} \text { Kg gula, maka } \\
\text { berapa Kg gula yang diperoleh Budi yang ingin menukar } 3 \\
\text { butir kelapa? (A) } \\
\begin{array}{lllll}\text { A. } 21 / 25 & \text { B. } 3 / 7 & \text { C. } 25 / 21 & \text { D. } 1 & \text { E. } 7 / 3\end{array}\end{array}$ \\
\hline & 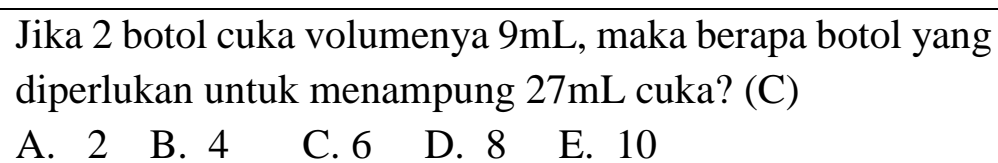 \\
\hline & $\begin{array}{l}\text { Seorang pengusaha barang bekas menukar } 4 \text { karung kertas } \\
\text { bekas masyarakat dengan } 7 \mathrm{Kg} \text { bawang merah. Berapa } \\
\text { karung kertas bekas yang dibutuhkan Nina untuk ditukar } \\
\text { bawang merah sebanyak } 5 \mathrm{Kg} \text { ? (B) } \\
\begin{array}{lllll}\text { A. } 3,257 & \text { B. } 2,857 & \text { C. } 3,355 & \text { D. } 4,859 & \text { E. } 5\end{array}\end{array}$ \\
\hline
\end{tabular}

Hasil tes kemampuan matematis kemudian dijumlahkan secara keseluruhan untuk dihitung masing-masing siswa berdasarkan rata-rata kelas. Hasil perhitungan tersebut akan mengkategorikan siswa dengan kemampuan matematis tinggi dan rendah. Berikut ini disajikan ringkasan hasil tes kemampuan matematis siswa;

Tabel 3. Ringkasan Hasil Tes Kemampuan Matematis

\begin{tabular}{|l|l|}
\hline \multicolumn{1}{|c|}{ KATEGORI } & $\begin{array}{c}\text { JUMLAH } \\
\text { (PROSENTASE) }\end{array}$ \\
\hline Kemampuan Matematis Tinggi (KMT) & 93 siswa $(77,5 \%)$ \\
\hline Kemampuan Matematis Rendah (KMR) & 27 siswa $(22,5 \%)$ \\
\hline
\end{tabular}

Berpijak pada Tabel 3 diatas, maka diperoleh hasil 93 siswa masuk pada klasifikasi dengan kemampuan matematis tinggi sedangkan 27 siswa dengan kemampuan matematis rendah. Oleh karenanya dapat dinyatakan bahwa responden didominasi oleh siswa dengan kemampuan matematis tinggi.

Dalam perhitungan uji normalitas dan homogenitas (Sugiono, 2014) data diperoleh hasil uji menggunakan SPSS sebagai berikut; 
Tabel 4. Hasil Uji Normalitas Data

\begin{tabular}{|l|c|c|}
\hline \multirow{2}{*}{ Kriteria Pengelompokan Data } & \multicolumn{2}{c|}{ P-Value } \\
\cline { 2 - 3 } & Kognitif & Afektif \\
\hline Model Pembelajaran STM & $>0.100$ & $>0.100$ \\
\hline Kemampuan Matematis Tinggi & $>0.100$ & $>0.100$ \\
\hline Kemampuan Matematis Rendah & $>0.100$ & $>0.100$ \\
\hline
\end{tabular}

Berdasarkan hasil uji pada tabel 4 di atas, terlihat bahwa hasil tiap uji normalitas diperoleh P-Value $>0.05$, maka diperoleh kesimpulan Ho ditolak, sehingga dapat dinyatakan bahwa data terdistribusi normal.

Tabel 5. Hasil Uji Homogenitas Data

\begin{tabular}{|l|c|c|}
\hline \multirow{2}{*}{\multicolumn{1}{|c|}{ Kriteria }} & \multicolumn{2}{c|}{ P-Value } \\
\cline { 2 - 3 } & Kognitif & Afektif \\
\hline Model Pembelajaran STM & 0.051 & 0.676 \\
\hline Kemampuan Matematis Tinggi & 0.083 & 0.272 \\
\hline Kemampuan Matematis Rendah & 0.098 & 0.309 \\
\hline
\end{tabular}

Berdasarkan tabel 5 di atas maka diperoleh P-Value > 0.05, sehingga diperoleh kesimpulan Ho ditolak. Hal ini berarti bahwa data mempunyai varian yang sama atau homogen. Dengan hasil normalitas dan homogenitas diatas, maka uji prasyarat terpenuhi sehingga uji hipotesis dpat dilakukan dengan uji parsial atau uji beda.

Berikut ini disajikan hasil uji hipotesis untuk melihat ada atau tidaknya pengaruh penerapan model Sains Teknologi Masyarakat terhadap hasil belajar, yaitu:

Tabel 6 Hasil Uji Hipotesis

\begin{tabular}{|l|c|}
\hline \multicolumn{1}{|c|}{ Variabel } & P-Value \\
\hline Model STM & 0.004 \\
\hline Kemampuan Matematis & 0.005 \\
\hline
\end{tabular}

Berdasarkan Tabel 6 di atas, diperoleh P-Value > 0.05, maka diperoleh kesimpulan Ho ditolak pada dua variabel uji ini berarti dapat dinyatakan bahwa terdapat pengaruh model pembelajaran Sains Teknologi Masyarakat terhadap hasil belajar ditinjau dari kemampuan matematis.

Bertolak dari hasil uji sebagaimana dipaparkan sebelumnya, maka dapat dijelaskan hasil tersebut sebagai berikut. Model pembelajaran Sains Teknologi 
Masyarakat menerapkan pembelajaran sains teknologi yang dihubungkan langsung dengan kehidupan nyata atau realitas sosial. Dengan hal tersebut maka siswa akan lebih efektif manangkap materi pelajaran dibandingkan model atau metode lain yang hanya mengacu pada teks atau konsep belaka. Selain itu N. Yoruk et al (2010) dalam studinya mengenai efek dari pembelajaran STM dalam pembelajaran menyimpulkan terdapat hubungan antara yang dipelajari dan yang dialami dalam kehidupan nyata memberikan efek positif terhadap pembelajaran. Ketidakterhubungnya antara apa yang dipelajari siswa dengan apa yang mereka alami dalam kehidupan nyata menjadikan menurunnya ketertarikan dalam pelajaran. Alasan ini telah menjawab adanya pengaruh model pembelajaran Sains Teknologi Masyarakat terhadap hasil belajar siswa.

Sedangkan terkait dengan adanya tinjauan kemampuan matematis yang dalam penelitian ini diperoleh hasil bahwa responden lebih dominan pada kategori kemampuan matematis tinggi dan siswa dengan kategori tersebut lebih cenderung mempunyai hasil belajar tinggi pula. Perbedaan kemampuan matematis seseorang (Adams, 2007) berkaitan dengan: 1) genetics, beberapa penelitian telah menunjukkan bahwa kemampuan matematik seorang anak ataupun yang telah dewasa mempunyai kaitan kuat dengan faktor genetik. 2) cognition, perbedaan tingkat kemampuan matematika dilihat dari ketepatan penghitungan. 3) behaviural, tingkat rasa takut terhadap matematika dapat mempengaruhi kapasitas kerja otak. Semakin tinggi rasa takut terhadap matematika akibatnya adalah penurunan kapasitas kerja otak.

\section{KESIMPULAN DAN SARAN}

Penelitian ini mempunyai kesimpulan yaitu terdapat pengaruh model pembelajaran Sains Teknologi Masyarakat terhadap hasil belajar ditinjau dari kemampuan matematis siswa kelas VII SMPN 2 Ambulu dan SMPN 2 Rambipuji Semester Ganjil Tahun Pelajaran 2018/2019.

Berdasarkan hasil penelitian ini maka peneliti memiliki saran sebagai berikut; 1) Hendaknya penelitian ini dijadikan acuan penelitian berikutnya sehingga akan lebih sempurna dan berkembang, 2) Guru hendaknya mempertimbangkan model pembelajaran Sains Teknologi Masyarakat untuk diterapkan adalam pembelajaran dan

3) Guru ataupun praktisi pendidikan memperhatikan aspek kemampuan matematis 
yang sangat membantu dalam daya tangkap terhadap materi pelajaran khususnya yang bernuansa hitungan.

\section{REFERENSI}

Arikunto, Suharsimi. 2002. Prosedur Penelitian. Jakarta: Renika Cipta

Adams, John W.2007. Individual differences in mathematical ability: genetic, cognitive and behavioural factors. Journal of Research in Special Educational Needs Volume 7 Number 2007 hal 97-103.

Kovas, Yulia et. al.2007. Mathematical Ability of 10-Year-Old Boys and Girls: Genetic and Environmental Etiology of Typical and Low Performance. Journal of Learning Disabilities 2007; 40; 554. DOI: 10.1177/00222194070400060601.

Panji Hidayat. 2009. Metode Science Technology Society (STS) dengan Eksperimen dan Proyek pada Materi Elektrokimia ditinjau dari Emotional Quotient (EQ) Siswa. Tesis S2 UNS. Surakarta.

Sugiono. 2014. Metode Penelitian Pendidikan Pendekatan Kuantitatif, Kualitatif, dan R\&D. Bandung: Alfabeta.

Yoruk, Nuray, etc. 2010. The Effects of Science, Technology, Society, Environment (STSE) interactions on teaching chemistry. Chemistry Education, Ankara, Turki 